\title{
The effect of low-level laser therapy on functional improvements in the temporomandibular joints: randomized clinical trial
}

\author{
O efeito da terapia a laser de baixo potência na funcionalidade da articulação temporomandibular: \\ ensaio clínico randomizado
}

EI efecto de la terapia láser de baja potencia sobre la funcionalidad de la articulación temporomandibular: un ensayo clínico aleatorizado

Received: 03/28/2021 | Reviewed: 04/04/2021 |Accept: 04/06/2021 | Published: 04/1 8/2021

\author{
Nirlley Karcia da Silva Veras \\ ORCID: https://orcid.org/0000-0002-7917-6222 \\ Federal University of Delta of Parnaíba, Brazil \\ E-mail: nirlleykarcia@hotmail.com \\ Antônia Mykaele Cordeiro Brandão \\ ORCID: https://orcid.org/0000-0001-8073-9339 \\ Federal University of Delta of Parnaíba, Brazil \\ E-mail: mykaelecordeiro@yahoo.com.br \\ Francisco Lázaro Arruda \\ ORCID: https://orcid.org/0000-0003-3277-0782 \\ Federal University of Ceará, Brazil \\ E-mail: flazaroarruda@gmail.com \\ Fernanda Mello da Silva Sousa \\ ORCID: https://orcid.org/0000-0003-0297-6472 \\ Federal University of Delta of Parnaíba, Brazil \\ E-mail: fernandamello64@gmail.com \\ Guilherme Pertinni de Morais Gouveia \\ ORCID: https://orcid.org/0000-0001-6470-2341 \\ Federal University of Delta of Parnaíba. Brazil \\ E-mail: gpfatufpi@gmail.com
}

\begin{abstract}
Introduction: Temporomandibular disorders (TMD) - recognized as the most common chronic orofacial pain condition - significantly impacts individuals' quality of life and social coexistence. Therefore, this study aimed to analyze the effects of low-level laser therapy (LLLT) on functional improvements in the temporomandibular joints (TMJ). Method: The research was carried out at the Universidade Federal do Piauí on 32 young adults with signs and symptoms of TMD, who were divided into the intervention group (IG) and the control group (CG). The IG was administered the LLLT application directly on the TMJ. While both groups were subjected to the same procedures, for the CG, the laser device was turned off. Results: The mean age of the participants was $21.87 \pm 2.4$ years, with a predominance of females $(87.5 \%)$ over males $(12.5 \%)$. Homogeneity was observed between the CG and IG concerning the presence of pain from palpation. The decrease in the pain of the musculature was relevant, with emphasis on the IG, which used LLLT. Moreover, there was an increase in participants, who rated on the pain scale their pain as " 0 " (no pain), and presented increased measures of joint mobility of the mandible and cervical spine, with relief of the painful symptoms, by breaking the pain-spasm-pain cycle. Conclusion: LLLT promotes a significant reduction of pain from palpation, improves the range of motion, and generates immediate and long-lasting benefits.
\end{abstract}

Keywords: Temporomandibular joint; Muscle pain; Physiotherapy modalities; Laser.

\section{Resumo}

Introdução: As disfunções temporomandibulares (DTM) - reconhecidas como a condição de dor orofacial crônica mais comum - têm um impacto significativo na qualidade de vida e na coexistência social dos indivíduos. Portanto, este estudo teve como objetivo analisar os efeitos da terapia a laser de baixa potência (LBP) na melhora funcional da articulação temporomandibular (ATM). Método: A pesquisa foi realizada na Universidade Federal do Piauí com 32 adultos jovens com sinais e sintomas de DTM, que foram divididos em grupo intervenção (GI) e grupo controle (GC). O GI foi administrado o aplicativo LBP diretamente na ATM. Enquanto os dois grupos foram submetidos aos mesmos procedimentos, para o GC o aparelho a laser foi desligado. Resultados: A média de idade dos participantes foi de $21,87 \pm 2,4$ anos, com predomínio do sexo feminino (87,5\%) sobre o masculino (12,5\%). Observou-se homogeneidade entre o GC e GI quanto à presença de dor à palpação. A diminuição da dor da musculatura foi relevante, com destaque para o GI, que utilizou LBP. Além disso, houve aumento dos participantes, que classificaram 
na escala de dor sua dor como "0" (sem dor), e apresentaram aumento nas medidas de mobilidade articular da mandíbula e coluna cervical, com alívio dos sintomas dolorosos, pela fratura do ciclo dor-espasmo-dor. Conclusão: O LBP promove uma redução significativa da dor à palpação, melhora a amplitude de movimento e gera benefícios imediatos e duradouros.

Palavras-chave: Articulação temporomandibular; Dor muscular; Modalidades de fisioterapia; Laser.

\section{Resumen}

Introducción: Los trastornos temporomandibulares (TTM), reconocidos como la condición de dolor orofacial crónico más común, tienen un impacto significativo en la calidad de vida y la convivencia social de las personas. Por lo tanto, este estudio tuvo como objetivo analizar los efectos de la terapia con láser de baja potencia (LBP) sobre la mejora funcional de la articulación temporomandibular (ATM). Método: La investigación se llevó a cabo en la Universidad Federal de Piauí con 32 adultos jóvenes con signos y síntomas de TTM, que se dividieron en un grupo de intervención (GI) y un grupo de control (GC). A la GI se le administró la aplicación LBP directamente en el cajero automático. Si bien los dos grupos fueron sometidos a los mismos procedimientos, para el CG se apagó el dispositivo láser. Resultados: La edad media de los participantes fue de 21,87 \pm 2,4 años, con predominio del sexo femenino (87,5\%) sobre el masculino (12,5\%). Hubo homogeneidad entre el GC y el GI en cuanto a la presencia de dolor a la palpación. La disminución del dolor muscular fue relevante, con énfasis en GI, que utilizó dolor lumbar. Además, hubo un aumento en los participantes, que calificaron su dolor en la escala de dolor como "0" (sin dolor), y mostraron un aumento en las medidas de movilidad articular de la mandíbula y la columna cervical, con alivio de los síntomas dolorosos, debido a la fractura del ciclo del dolor - espasmo-dolor. Conclusión: El dolor lumbar promueve una reducción significativa del dolor a la palpación, mejora el rango de movimiento y genera beneficios inmediatos y duraderos.

Palabras clave: Articulación temporomandibular; Dolor muscular; Modalidades de fisioterapia; Láser.

\section{Introduction}

The temporomandibular joint (TMJ) is seen as one of the most complex joints of the human body, formed by the articulation of the condylar head of the mandible and the glenoid fossa of the temporal bone, classified as ginglymusarthrodial. It is considered a bicondylar joint, since it works simultaneously on both ends of the mandible, and presents a biconcave disc responsible for the protection of the articular structure by facilitating contact between the bone surfaces during the protrusion, retrusion, opening, and closing movements, and mandibular laterality (Aires et al., 2020; Bag et al., 2014; Lima et al., 2020).

The TMJ is among the most used joints since it moves about 2000 times a day. Its structure is totally composed of members of the stomatognathic system, responsible for functions of extreme importance like talking, yawning, chewing, swallowing, and breathing (Freitas et al., 2015; Vilar et al., 2020).

When due to some factors, there is alteration in the biomechanics of this joint, it can be affirmed that there is a dysfunction. Temporomandibular disorders (TMD) is characterized by a series of clinical signs and symptoms that could affect the TMJ, masticatory muscles, and associated structures, and alter the stomatognathic system homeostasis (Calixtre et al., 2015).

Epidemiological studies indicate that about $40 \%$ to $75 \%$ of the world's population manifest at least one indicator of TMD — noises or crackling in the TMJ — and 33\% at least one symptom — facial or TMJ pain. Although currently, in Brazil, there are few studies demonstrating the prevalence of signs and symptoms of TMD in large population samples; a recent study found that $37.5 \%$ of the population had at least one TMD symptom (Dantas et al., 2015; G. C. B. da Silva et al., 2021).

TMD is caused by multifactorial origins, such as joint trauma, occlusal discrepancies, joint hypermobility, skeletal problems, psychosocial and behavioral factors, besides parafunctional habits, which are considered as its major cause. Those afflicted with this disorder may present several symptoms, such as joint noises (clicks and crepitations); decreased mandibular range of motion (ROM); pain in the TMJ and masticatory muscles; tinnitus; otalgia; headaches; dizziness and vertigo; and psychological disorders, including fatigue, insomnia, anxiety, and depression (Dantas et al., 2015). 
The painful conditions of TMD may be temporary or recurrent, presenting a set of alterations that lead to the appearance of disorders in the masticatory muscles and the joint itself, triggering generalized pain in different parts of the body, and in cervical pain, for example, these disorders are usually directly related to stress (Freitas et al., 2015; Sobral et al., 2020).

According to the signs and symptoms mentioned by individuals, the functional diagnosis of TMD intended for TMJ evaluation is given using a series of instruments, such as the: Pachymeter-widely used to measure the ability of mandibular movements, palpations in the mandibular region and all masticatory muscles; Visual analog scale (VAS) - a great ally to measure each patient's pain; Fonseca Anamnesic Index (Fonseca 1998) - to diagnose the presence and level of TMD; and the Helkimo Index - to rank the clinical signs of TMD based on the severity category (Garcia \& Oliveira, 2011).

In the treatment of TMD, a range of physiotherapeutic resources-manual therapy, thermotherapy, cryotherapy, kinesiotherapy, and electrotherapy — are widely used (Damasceno \& Barbieri, 2014). Low-level laser therapy (LLLT) is a lowcost non-invasive treatment modality, which has shown excellent results in reducing the condition as well as tissue restoration. Its therapeutic effects include: reduced inflammation, analgesia, and modulation of cellular activity (Gama et al., 2015).

TMD — recognized as the most common chronic orofacial pain condition—significantly impacts individuals' quality of life and social coexistence. Talking, feeding, breathing, and other activities that require the involvement of TMJ are indispensable for human survival (A. Silva \& Santos, 2014). Moreover, since it is known that the field of physical therapy is little-explored, as compared to the high incidence of TMD, for creating greater awareness of this specialty, there is a necessity for new studies as well as the emergence of effective therapies for enabling the return of functionality of this articulation, as well as the dissemination of knowledge among professionals and academics. Therefore, this study aimed to analyze the effect of LLLT on the functional improvement of the TMJ.

\section{Methodology}

\section{Type of study}

It was a randomized sham-controlled double-blind clinical trial. This type of study is currently considered the gold standard in evidence-based practice, being at the top of the scientific pyramid. This has the purpose of evaluating the effectiveness of some intervention, such as obtaining subsidies to support the use of a therapy or others, comparing the intervention with the sham or placebo, and with this directing the conduct of health professionals through consistent scientific observations (Chaudhry et al., 2008; Prado et al., 2018; Soucacos et al., 2008). In this context, the randomized clinical trial reduces the possibility of confounding effect and selection bias (Malavolta et al., 2011).

\section{Location and Search Period}

The research was developed at the Universidade Federal do Piauí (UFPI)'s Clinical School of Physiotherapy during August to December 2017.

\section{Ethical aspects}

It took place in accordance with the ethical principles of Resolution 466/12 of the National Health Council (Maria \& Andrade, 2013), and was approved by the UFPI's Research Ethics Committee, under number 2.309.198, in accordance with the four basic principles of bioethics - autonomy, non-maleficence, beneficence, and justice — and the number of clinical trials on the REBEC platform RBR-34ZQRC. 
The researchers explained the objectives and steps of the study to the patients meeting the inclusion criteria, who then signed the informed consent form (ICF).

\section{Population and sample}

The study consisted of 32 students of the UFPI manifesting signs and symptoms of TMD, who were divided into two groups: IG and CG, each with 16 volunteers, randomized through a simple draw.

\section{Inclusion criteria}

This study's participants included young adults (aged 18 to 25 years) regardless of gender, who had registered in the clinical sector of the physiotherapy school, and had agreed to participate in the study by signing the ICF. They were selected based on an evaluation form containing identifications: Fonseca Anamnestic Index for the detection of parafunctional habits and TMJ functional examination, as well as the Helkimo Index for the detection of clinical signs of mandibular cranial dysfunction, besides anamnesis with inspection, palpation, and use of the caliper to verify joint openings and the degree of mobility. Thereafter, those eligible were invited to participate in the study, and the objectives were explained to them, post which, they read and signed the ICF.

The research population included academics from the ufpi, who were administered specific questionnaires (fonseca anamnestic index and helkimo index) for evaluating their functionality, and if it presented any degree of severity of tmd. Subsequent to the questionnaire, screening of those who fit the research was carried out, and forwarded to the ufpi's laboratory of evaluative and therapeutic physiotherapy.

\section{Exclusion criteria}

The participants, who used: fixed or mobile orthodontic braces or plaque for correction, anti-inflammatory drugs or muscle relaxants, or had any other pathogenies that alter the functionality of TMJ were excluded from the study.

\section{Instruments and procedures for data collection}

For better data collection, the researchers were trained in all the collection instruments and procedures, but for avoiding any selection and analysis bias, it was decided that each step would be performed only by one researcher during the entire research.

The participants were divided into two groups: IG and CG, each having 16 individuals. The interventions which were held thrice a week (always during the afternoons) comprised of 10 attendances in all, , with both groups being submitted to the same procedures, but in the CG, the laser device was turned off (sham). The IG was subjected to the application of the low power laser of the brand Endophoton, model LLT0107 (660 nm $35 \mathrm{~mW})$ with a wavelength of $830 \mathrm{~nm}$ and an average power of $120 \mathrm{~mW}$, directly on the TMJ, with a dosage of $3 \mathrm{~J} / \mathrm{cm}^{2}$, during $40 \mathrm{sec}$ (Gama et al., 2015). The application was performed directly on the TMJ, bilaterally, with the individuals in dorsal decubitus (lying with their back in contact with the stretcher), totally relaxed, without any voluntary movements. Asepsis of the entire region was performed with 70\% alcohol, making the skin free of any oils. Figure 1 represents the flowchart of the research steps. 
Figure 1. Flowchart of the study population, including the number of volunteers who were selected, consented, submitted to randomization, completed the study treatment and were included in the analysis.

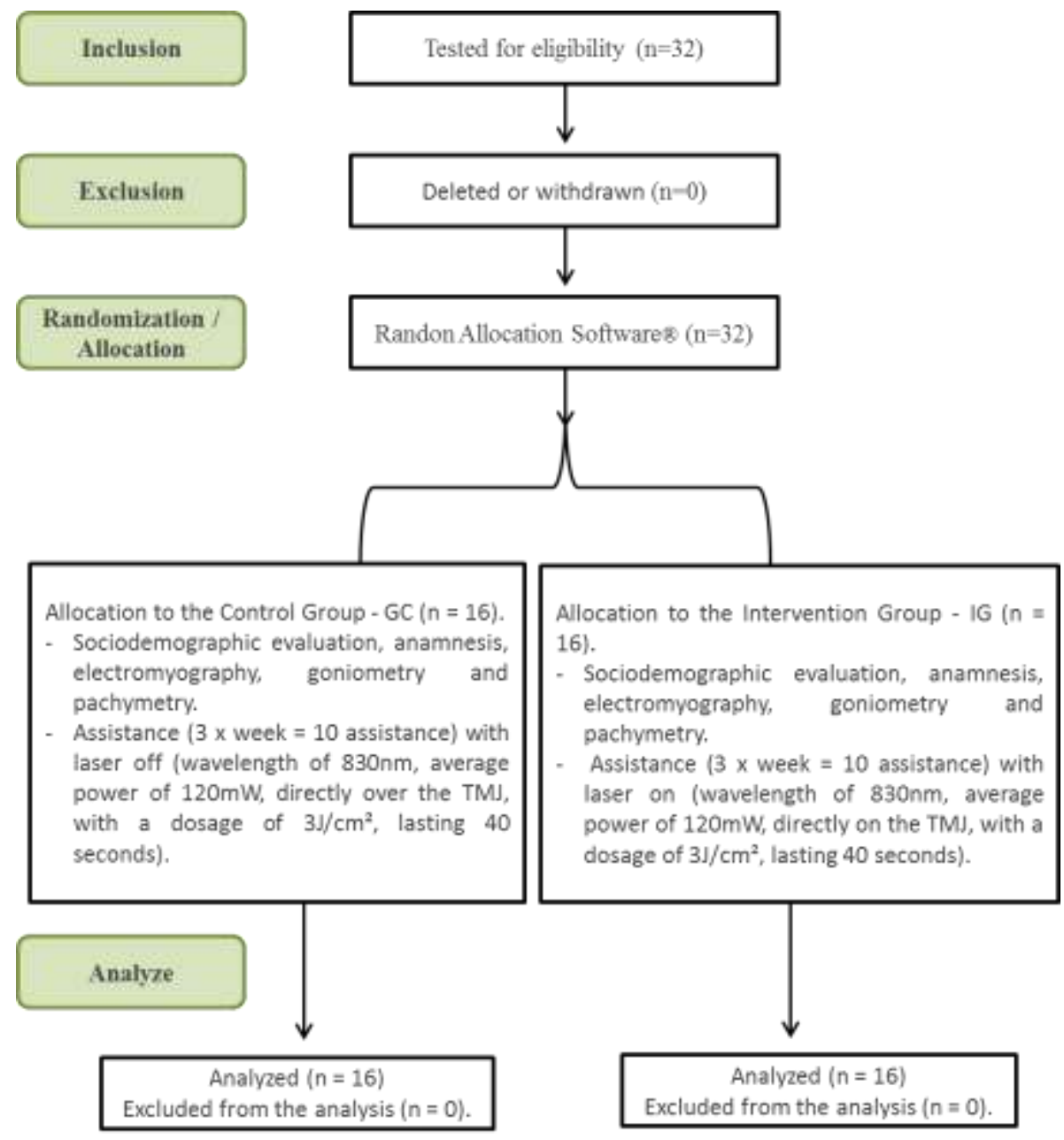

Fonte: Authors.

\section{Data analysis}

Data were entered into a database using the Epi Info program (version 6.04d, Centers for Disease Control and Prevention, USA). Data analysis was performed using SPSS software (version 21.0).

Initially, descriptive statistic was performed, including tabulations according to the selected variables, and then, the normality of the data were verified (Kolmogorov-Smirnov), using simple frequency distribution of the variables of interest of the study, chi-square association tests to analyze association between outcome and exploratory variations, student t-test for independent samples, Kruskal Wallis, Bonferroni post hoc ANOVA test, paired-sample t-test, and 95\% confidence interval (CI).

Statistical significance was considered when $\mathrm{p}<0.05$. Subsequently, the results were presented as tables.

\section{Research Risks and Benefits}

This research brought minimal risks, but if any of the participants reported any discomfort, they would be offered all necessary support, such as referral to a physiotherapy clinic or reference hospital in the city.

Participants were guaranteed absolute anonymity as well as confidentiality of their information, without any risk or prejudice to their activities with the group of participants, as well as the right to withdraw from the research at any time. There were also no bonuses or burdens on participants and researchers. 
The obtained data were used in a strictly scientific manner, with the aim of contributing to the formation and diffusion of scientific knowledge.

\section{Results}

\section{Sociodemographic characteristics and clinical profiles of the research participants}

This study, which included 32 volunteers, equally divided into two groups: IG and CG, had a majority of female participants (87.5\%), with a mean age of $21.87 \pm 2.4$ years, median of 21 years, ranging from 19 to 25 years. In the CG, both the males and females were aged 22 years; whereas in the IG, the ages of the males and females were 21.7 years and 21.3 years, respectively.

Data of clinical variables-the Fonseca Anamnestic index, Helkimo index, opening alterations, and TMJ auscultation - were presented with normal distribution. Prior to this, during statistical inference of the data between groups, by using the t-test for independent samples and the Kruskal Wallis, a similarity (homogenization) of the results with $p>0.05$ was noticed, as shown in Table 1, which presents a detailed description of these characteristics.

Table 1 - Sociodemographic and clinical characteristics of group volunteers, Parnaíba, 2018.

\begin{tabular}{|c|c|c|c|c|}
\hline \multicolumn{2}{|c|}{ Variables } & \multirow{2}{*}{$\begin{array}{c}\begin{array}{c}\text { Control } \\
\text { Group }(\mathbf{n}=16)\end{array} \\
22.0(2.2)\end{array}$} & \multirow{2}{*}{$\begin{array}{c}\begin{array}{c}\text { Intervention } \\
\text { Group (n=16) }\end{array} \\
21.6(1.5)\end{array}$} & \multirow{2}{*}{$\begin{array}{c}\text { p-value } \\
0.078 *\end{array}$} \\
\hline Age (years), av ( & & & & \\
\hline & Female & $15(93.7)$ & $13(81.2)$ & $0.065^{* *}$ \\
\hline Gender, n (\%) & Male & $01(6.3)$ & $03(18.8)$ & $0.089 * *$ \\
\hline \multirow{3}{*}{ Fonseca Index, n (\%) } & Mild & $06(37.4)$ & $02(12.4)$ & $0.235^{* *}$ \\
\hline & Moderate & $05(31.3)$ & $07(43.8)$ & $0.310 * *$ \\
\hline & Severe & $05(31.3)$ & $07(43.8)$ & $0.112 * *$ \\
\hline \multirow{3}{*}{ Helkimo Index, n (\%) } & Mild dysfunction & $08(50.0)$ & $03(18.8)$ & $0.478 * *$ \\
\hline & Moderate dysfunction & $05(31.2)$ & $05(31.2)$ & $0.978 * *$ \\
\hline & Severe dysfunction & $03(18.8)$ & $08(50.0)$ & $0.875^{* *}$ \\
\hline \multirow{5}{*}{$\begin{array}{l}\text { Alteration in mouth opening, } \\
\text { n }(\%)\end{array}$} & Nonexistent & $06(37.5)$ & $09(56.3)$ & $0.452 * *$ \\
\hline & Deviation to the right & $02(12.4)$ & $0(0.0)$ & $0.252 * *$ \\
\hline & Deviation to the left & $01(6.3)$ & $01(6.2)$ & $0.365^{* *}$ \\
\hline & Left deflection & $01(6.3)$ & $01(6.2)$ & $0.124 * *$ \\
\hline & Right deflection & $06(37.5)$ & $05(31.3)$ & $0.687 * *$ \\
\hline \multirow{4}{*}{ TMJ auscultation, n (\%) } & No noise & $12(75.0)$ & $10(62.5)$ & $0.315^{* *}$ \\
\hline & Crackling Presence & $03(18.8)$ & $02(12.5)$ & $0.221 * *$ \\
\hline & Click on opening & $01(6.2)$ & $02(12.5)$ & $0.175^{* *}$ \\
\hline & Click on opening and closing & $0(0.0)$ & $02(12.5)$ & $0.851 * *$ \\
\hline
\end{tabular}

TMJ - Temporomandibular joint; av - absolute value; $\mathrm{n}$ - sample; * t test for independent samples; ** Kruskal Wallis test. Source: Authors.

Data for clinical variables such as maximal opening, protrusion, laterality, and cervical ROM were presented with a normal distribution. Prior to making inferences related to data between the groups, by using the t-test for independent samples and the Kruskal Wallis test, as shown in Tables 2 and 3, respectively, a similarity of the results was noticed with p >0.05. 
Table 2 - Clinical characteristics of palpation of the muscles related to TMJ of the research volunteers, moment before the intervention, Parnaíba, 2018.

\begin{tabular}{|c|c|c|c|c|c|c|c|c|}
\hline & \multirow{2}{*}{$\begin{array}{l}\text { Variables } \\
\text { Muscles }\end{array}$} & \multicolumn{3}{|c|}{$\begin{array}{l}\text { Control Group }(n=16) \\
\text { Before (SD) }\end{array}$} & \multicolumn{3}{|c|}{$\begin{array}{c}\text { Intervention Group }(n=16) \\
\text { Before (SD) }\end{array}$} & \multirow[t]{2}{*}{ p-value ${ }^{* *}$} \\
\hline & & Painless & $\begin{array}{l}\text { Mild } \\
\text { pain }\end{array}$ & $\begin{array}{l}\text { Moderate } \\
\text { pain }\end{array}$ & Painless & $\begin{array}{l}\text { Mild } \\
\text { pain }\end{array}$ & $\begin{array}{l}\text { Moderate } \\
\text { pain }\end{array}$ & \\
\hline \multirow{14}{*}{$\begin{array}{l}\text { Palpation, } n \\
(\%)\end{array}$} & Right SCM & $\begin{array}{c}08 \\
(50.0) \\
\end{array}$ & $\begin{array}{c}04 \\
(25.0) \\
\end{array}$ & $04(25.0)$ & $\begin{array}{c}10 \\
(62.4) \\
\end{array}$ & $\begin{array}{c}03 \\
(18.8) \\
\end{array}$ & $03(18.8)$ & 0.865 \\
\hline & Left SCM & $\begin{array}{c}06 \\
(37.4) \\
\end{array}$ & $\begin{array}{c}05 \\
(31.3) \\
\end{array}$ & $05(31.3)$ & $\begin{array}{c}12 \\
(75.0) \\
\end{array}$ & $0(0.0)$ & $04(25.0)$ & 0.147 \\
\hline & Right Masseter & $\begin{array}{c}13 \\
(81.2) \\
\end{array}$ & $\begin{array}{c}03 \\
(18.8) \\
\end{array}$ & $0(0.0)$ & $\begin{array}{c}11 \\
(68.8)\end{array}$ & $\begin{array}{c}03 \\
(18.8) \\
\end{array}$ & $02(12.4)$ & 0.256 \\
\hline & Left Masseter & $\begin{array}{c}11 \\
(68.8)\end{array}$ & $\begin{array}{c}04 \\
(25.0)\end{array}$ & $01(6.2)$ & $\begin{array}{c}09 \\
(56.3)\end{array}$ & $\begin{array}{c}06 \\
(37.5)\end{array}$ & $01(6.2)$ & 0.408 \\
\hline & Right Temporal & $\begin{array}{c}11 \\
(68.8)\end{array}$ & $\begin{array}{c}03 \\
(18.8)\end{array}$ & $02(12.4)$ & $\begin{array}{c}09 \\
(56.3)\end{array}$ & $\begin{array}{c}03 \\
(18.7)\end{array}$ & $04(25.0)$ & 0.321 \\
\hline & Left Temporal & $\begin{array}{c}11 \\
(68.8)\end{array}$ & $\begin{array}{c}03 \\
(18.8)\end{array}$ & $02(12.4)$ & $\begin{array}{c}10 \\
(62.5)\end{array}$ & $\begin{array}{c}02 \\
(12.5)\end{array}$ & $04(25.0)$ & 0.856 \\
\hline & Right medial pterygoid & $\begin{array}{c}10 \\
(62.5) \\
\end{array}$ & $\begin{array}{c}05 \\
(31.3) \\
\end{array}$ & $01(6.2)$ & $\begin{array}{c}04 \\
(25.0) \\
\end{array}$ & $\begin{array}{c}06 \\
(37.5) \\
\end{array}$ & $06(37.5)$ & 0.079 \\
\hline & Left medial pterygoid & $\begin{array}{c}11 \\
(68.8)\end{array}$ & $\begin{array}{c}02 \\
(12.4) \\
\end{array}$ & $03(18.8)$ & $\begin{array}{c}05 \\
(31.3) \\
\end{array}$ & $\begin{array}{c}06 \\
(37.4) \\
\end{array}$ & $05(31.3)$ & 0.751 \\
\hline & Right lateral pterygoid & $\begin{array}{c}07 \\
(43.7) \\
\end{array}$ & $\begin{array}{c}06 \\
(37.5) \\
\end{array}$ & $03(18.8)$ & $\begin{array}{c}06 \\
(37.5) \\
\end{array}$ & $\begin{array}{c}03 \\
(18.8) \\
\end{array}$ & $07(43.7)$ & 0.085 \\
\hline & Left lateral pterygoid & $\begin{array}{c}08 \\
(50.0)\end{array}$ & $\begin{array}{c}03 \\
(18.8)\end{array}$ & $05(31.2)$ & $\begin{array}{c}08 \\
(50.0)\end{array}$ & $\begin{array}{c}04 \\
(25.0)\end{array}$ & $04(25.0)$ & 0.062 \\
\hline & Upper Right Trapezius & $\begin{array}{c}07 \\
(43.7) \\
\end{array}$ & $\begin{array}{c}03 \\
(18.8) \\
\end{array}$ & $06(37.5)$ & $\begin{array}{c}05 \\
(31.3) \\
\end{array}$ & $\begin{array}{c}04 \\
(25.0) \\
\end{array}$ & $07(43.7)$ & 0.136 \\
\hline & Upper Left Trapezius & $\begin{array}{c}07 \\
(43.7)\end{array}$ & $01(6.3)$ & $08(50.0)$ & $\begin{array}{c}05 \\
(31.3)\end{array}$ & $\begin{array}{c}06 \\
(37.4)\end{array}$ & $05(31.3)$ & 0.519 \\
\hline & Suboccipitals & $\begin{array}{c}07 \\
(43.7) \\
\end{array}$ & $\begin{array}{c}05 \\
(31.3) \\
\end{array}$ & $04(25.0)$ & $\begin{array}{c}10 \\
(62.5) \\
\end{array}$ & $\begin{array}{c}04 \\
(25.0) \\
\end{array}$ & $02(12.5)$ & 0.098 \\
\hline & Paravertebral & $\begin{array}{c}07 \\
(43.7) \\
\end{array}$ & $\begin{array}{c}04 \\
(25.0) \\
\end{array}$ & $05(31.3)$ & $\begin{array}{c}09 \\
(56.3) \\
\end{array}$ & $\begin{array}{c}02 \\
(12.4) \\
\end{array}$ & $05(31.3)$ & 0.123 \\
\hline
\end{tabular}

SCM - sternocleidomastoid; $\mathrm{n}$ - sample; ** Kruskal Wallis test. Source: Authors.

Table 3 - Clinical characteristics of TMJ and cervical range of motion of research volunteers, moment before the intervention, Parnaíba, 2018.

\begin{tabular}{|c|c|c|c|c|}
\hline & Variables & $\begin{array}{c}\text { Control Group } \\
(\mathbf{n = 1 6}) \\
\text { Before (SD) }\end{array}$ & $\begin{array}{c}\text { Intervention } \\
\text { Group } \\
(\mathbf{n}=16) \\
\text { Before (SD) }\end{array}$ & p-value * \\
\hline \multirow{10}{*}{$\begin{array}{l}\text { Range of } \\
\text { motion } \\
( \pm \text { SD })\end{array}$} & Maximum mouth opening (mm) & $33.7(9.6)$ & $33.8(8.9)$ & 0.652 \\
\hline & Mandibular protrusion $(\mathrm{mm})$ & $3.4(1.8)$ & $3.3(2.6)$ & 0.111 \\
\hline & Mandible lateralization to the right (mm) & $6.1(2.5)$ & $3.6(2.8)$ & 0.163 \\
\hline & Mandible lateralization to the left $(\mathrm{mm})$ & $6.2(3.3)$ & $3.2(2.3)$ & 0.104 \\
\hline & Cervical flexion $\left(^{\circ}\right)$ & $43.7(11.9)$ & $46.3(12.5)$ & 0.741 \\
\hline & Cervical extension $\left({ }^{\circ}\right)$ & $38.7(10.0)$ & $34.4(16.8)$ & 0.366 \\
\hline & Right cervical tilt $\left(^{\circ}\right)$ & $33.8(11.8)$ & $36.8(10.0)$ & 0.099 \\
\hline & Left cervical tilt $\left(^{\circ}\right)$ & $34.6(13.3)$ & $35.4(12.2)$ & 0.851 \\
\hline & Right cervical rotation $\left(^{\circ}\right)$ & $44.6(13.3)$ & $48.2(17.8)$ & 0.985 \\
\hline & Left cervical rotation $\left({ }^{\circ}\right)$ & $47.1(16.0)$ & $50.5(15.3)$ & 0.087 \\
\hline
\end{tabular}

$\mathrm{mm}$ - millimeter; SD - standard deviation; ${ }^{\circ}$ - degree; av - absolute value; $\mathrm{n}$ - sample; ${ }^{*}$ independent samples t-test. Source: Authors. 


\section{Muscle pain on palpation and ROM of temporomandibular and cervical joints}

When checking the effects of the protocols on muscle functionality relating to palpation pain, a significant improvement was observed in all the muscles in the IG, when compared to the intergroup p-value of the CG, as well as comparing the period before and after the protocols, and a considerable improvement was noted in the intragroup p-value of the IG. However, it was not possible to notice a statistically significant difference in the CG (see Table 4 for details).

Table 4 - Analysis of muscle pain on palpation, before and after the use of the low-power laser therapy protocol in TMD of the research volunteers, Parnaíba, 2018.

\begin{tabular}{|c|c|c|c|c|c|c|c|c|c|c|c|c|}
\hline \multirow{3}{*}{\multicolumn{2}{|c|}{ Muscles }} & \multicolumn{5}{|c|}{ Control Group } & \multicolumn{4}{|c|}{ Intervention Group } & \multirow{3}{*}{$\begin{array}{c}\text { intragr } \\
\text { oup p- } \\
\text { value } \\
(\mathrm{R} / \mathrm{L})\end{array}$} & \multirow{3}{*}{$\begin{array}{c}\text { Inter } \\
\text { group } \\
\text { p- } \\
\text { value } \\
(\mathrm{R} / \mathrm{L})\end{array}$} \\
\hline & & \multicolumn{2}{|c|}{$\begin{array}{l}\text { Mean } \\
\text { before }\end{array}$} & \multicolumn{2}{|c|}{ Mean after } & \multirow{2}{*}{$\begin{array}{c}\text { Intragrou } \\
\text { p p- value } \\
\text { (R/L) }\end{array}$} & \multicolumn{2}{|c|}{ Mean before } & \multicolumn{2}{|c|}{ Mean after } & & \\
\hline & & $\mathbf{R}$ & $\mathbf{L}$ & $\mathbf{R}$ & $\mathbf{L}$ & & $\mathbf{R}$ & $\mathbf{L}$ & $\mathbf{R}$ & $\mathbf{L}$ & & \\
\hline \multirow{3}{*}{ SCM } & No pain & 08 & 06 & 05 & 05 & \multirow{3}{*}{$\begin{array}{c}0.745 / \\
0.100\end{array}$} & 10 & 12 & 13 & 15 & \multirow{3}{*}{$\begin{array}{l}0.031 / \\
0.001^{\text {** }}\end{array}$} & \multirow{3}{*}{$0.02 / 0.002^{* *}$} \\
\hline & Mild & 04 & 05 & 03 & 02 & & 03 & 00 & 03 & 01 & & \\
\hline & $\begin{array}{l}\text { Moderate } \\
\text { pain }\end{array}$ & 04 & 05 & 08 & 09 & & 03 & 04 & 00 & 00 & & \\
\hline \multirow{3}{*}{ Masseter } & No pain & 13 & 11 & 14 & 13 & \multirow{3}{*}{$\begin{array}{c}0.158 / \\
0.553\end{array}$} & 11 & 09 & 12 & 12 & \multirow{3}{*}{$\begin{array}{l}0.001 / \\
0.002^{* * *}\end{array}$} & \multirow{3}{*}{$0.012 / 0.031^{* *}$} \\
\hline & Mild & 03 & 04 & 02 & 02 & & 03 & 06 & 03 & 02 & & \\
\hline & $\begin{array}{l}\text { Moderate } \\
\text { pain }\end{array}$ & 00 & 01 & 00 & 01 & & 02 & 01 & 01 & 02 & & \\
\hline \multirow{3}{*}{ Temporal } & No pain & 11 & 11 & 12 & 12 & \multirow{3}{*}{$\begin{array}{c}0.095 / \\
0.087\end{array}$} & 09 & 10 & 13 & 13 & \multirow{3}{*}{$\begin{array}{l}0.045 / \\
0.038^{* *}\end{array}$} & \multirow{3}{*}{$0.021 / 0.015^{* *}$} \\
\hline & Mild & 03 & 03 & 02 & 03 & & 03 & 02 & 02 & 01 & & \\
\hline & $\begin{array}{l}\text { Moderate } \\
\text { pain }\end{array}$ & 02 & 02 & 02 & 01 & & 04 & 04 & 01 & 02 & & \\
\hline \multirow{3}{*}{$\begin{array}{l}\text { Medial } \\
\text { Pterygoid }\end{array}$} & No pain & 10 & 11 & 11 & 12 & \multirow{3}{*}{$\begin{array}{c}0.128 / \\
0.216\end{array}$} & 04 & 05 & 10 & 09 & \multirow{3}{*}{$\begin{array}{l}0.020 / \\
0.012^{* *}\end{array}$} & \multirow{3}{*}{$0.005 / 0.010^{*}$} \\
\hline & Mild & 05 & 02 & 03 & 03 & & 06 & 06 & 04 & 05 & & \\
\hline & $\begin{array}{l}\text { Moderate } \\
\text { pain }\end{array}$ & 01 & 03 & 02 & 01 & & 06 & 05 & 02 & 02 & & \\
\hline \multirow{3}{*}{$\begin{array}{l}\text { Lateral } \\
\text { Pterygoid }\end{array}$} & No pain & 07 & 08 & 12 & 10 & \multirow{3}{*}{$\begin{array}{c}0.785 / \\
0.695\end{array}$} & 06 & 08 & 10 & 10 & \multirow{3}{*}{$\begin{array}{l}0.038 / \\
0.025^{* *}\end{array}$} & \multirow{3}{*}{$0.024 / 0.022^{* *}$} \\
\hline & Mild & 06 & 03 & 01 & 03 & & 03 & 04 & 03 & 02 & & \\
\hline & $\begin{array}{l}\text { Moderate } \\
\text { pain }\end{array}$ & 03 & 05 & 03 & 03 & & 07 & 04 & 03 & 04 & & \\
\hline & No pain & 07 & 07 & 07 & 07 & & 05 & 05 & 09 & 11 & & \\
\hline Upper & Mild & 03 & 01 & 04 & 04 & $0.087 /$ & 04 & 06 & 04 & 04 & $0.050 /$ & $0016 / 0015^{* * *}$ \\
\hline Trapezius & $\begin{array}{l}\text { Moderate } \\
\text { pain }\end{array}$ & 06 & 08 & 05 & 05 & 0.096 & 07 & 05 & 03 & 01 & $0.045^{* *}$ & נד \\
\hline & No pain & & & & & & & & & & & \\
\hline Suboccipi & $\begin{array}{l}\text { Mild } \\
\text { pain }\end{array}$ & & & & & 0.602 & & & & & $0.048^{* * *}$ & $0.032^{* *}$ \\
\hline & $\begin{array}{l}\text { Moderate } \\
\text { pain }\end{array}$ & & & & & & & & & & & \\
\hline & No pain & & & & & & & & & & & \\
\hline Paraverte & Mild & & & & & 0100 & & & & & $0030^{* *}$ & $0005^{* *}$ \\
\hline bral & $\begin{array}{l}\text { Moderate } \\
\text { pain }\end{array}$ & & & & & & & & & & & \\
\hline
\end{tabular}


SCM - sternocleidomastoid; R - right; L - left; ${ }^{* *}$ There was a statistical difference by the Kruskal Wallis test. Source: Authors.

To verify the effectiveness of laser therapy in muscle amplitude of the TMJ and cervical spine, goniometry and pachymetry were performed, before and after the interventions, in both the groups.

When analyzing the goniometry and pachymetry data for the following movements: maximum mouth opening, mandibular protrusion, right and left mandibular laterality, cervical flexion and extension, right and left cervical inclination, and right and left cervical rotation, using the Bonferroni post hoc ANOVA test; as compared with participants in the CG, those in IG had a significant increase for each variable after the intervention (intergroup p-values: $0.002 ; 0.001 ; 0.002 ; 0.0050 .025$; $0.015 ; 0.020 ; 0.002 ; 0.001$, and 0.001 , respectively), confirmed by the mean difference between groups with $95 \%$ CI. Table 5 presents the intragroup and intergroup data, as well as the $95 \% \mathrm{CI}$.

Table 5 - Range of motion analysis before and after the use of the low-power laser therapy protocol in TMD of the research volunteers, Parnaíba, 2018.

\begin{tabular}{|c|c|c|c|c|c|c|c|c|}
\hline \multirow{2}{*}{ Muscles } & \multicolumn{3}{|c|}{ Control Group } & \multicolumn{3}{|c|}{ Grupo Intervenção } & \multirow{2}{*}{$\begin{array}{c}\text { Mean } \\
\text { difference } \\
\text { between } \\
\text { groups } \\
\text { (C195\%) }\end{array}$} & \multirow{2}{*}{$\begin{array}{l}p \text {-value } \\
\text { tergrupo) }\end{array}$} \\
\hline & $\begin{array}{l}\text { Mean } \\
\text { after } \\
\text { (SV) }\end{array}$ & $\begin{array}{l}\text { Mean } \\
\text { after } \\
\text { (SV) }\end{array}$ & $\begin{array}{c}p \text {-value } \\
\text { (intragr } \\
\text { upo) }\end{array}$ & $\begin{array}{l}\text { Mean after } \\
\quad(\text { SV) }\end{array}$ & $\begin{array}{l}\text { Mean } \\
\text { after } \\
\text { (SV) }\end{array}$ & $\begin{array}{c}p \text {-value } \\
\text { (intragr } \\
\text { upo) }\end{array}$ & & \\
\hline $\begin{array}{l}\text { Maximum mouth opening } \\
\text { (mm) }\end{array}$ & $\begin{array}{l}33.7 \\
(9.6)\end{array}$ & $35.0(9.5)$ & 0.745 & $33.8(8.9)$ & $37.2(8.7)$ & $0.001^{\dagger}$ & $\begin{array}{c}1.3(-10.2- \\
7.5)\end{array}$ & $0.002^{\ddagger}$ \\
\hline Mandibular protrusion $(\mathrm{mm})$ & $3.4(1.8)$ & $4.2(1.9)$ & 0.158 & $3.3(2.6)$ & $4.8(2.2)$ & $0.025^{\dagger}$ & $\begin{array}{c}1.1(-7.7- \\
10.2) \\
\end{array}$ & $0.001^{\ddagger}$ \\
\hline $\begin{array}{l}\text { Mandible lateralization to the } \\
\text { right }(\mathrm{mm})\end{array}$ & $6.1(2.5)$ & $6.8(2.3)$ & 0.056 & $3.6(2.8)$ & $5.2(2.5)$ & $0.018^{\dagger}$ & $\begin{array}{l}2.5(-0.6- \\
5.0)\end{array}$ & $0.002^{*}$ \\
\hline $\begin{array}{l}\text { Mandible lateralization to the } \\
\text { left }(\mathrm{mm})\end{array}$ & $6.2(3.3)$ & $6.5(3.3)$ & 0.095 & $3.2(2.3)$ & $5.5(2.1)$ & $0.001^{\dagger}$ & $\begin{array}{l}3.0(-0.4- \\
6.0)\end{array}$ & $0.005^{*}$ \\
\hline Cervical flexion $\left(^{\circ}\right)$ & $\begin{array}{c}43.7 \\
(11.9) \\
\end{array}$ & $\begin{array}{c}45.1 \\
(11.6) \\
\end{array}$ & 0.604 & $46.3(12.5)$ & $\begin{array}{c}48.9 \\
(11.2) \\
\end{array}$ & $0.001^{\dagger}$ & $\begin{array}{c}2.5(-8.9- \\
14.0) \\
\end{array}$ & $0.025^{*}$ \\
\hline Cervical extension $\left({ }^{\circ}\right)$ & $\begin{array}{c}38.7 \\
(10.0) \\
\end{array}$ & $41.0(9.8)$ & 0.269 & $34.4(16.8)$ & $\begin{array}{c}40.1 \\
(11.3) \\
\end{array}$ & $0.010^{\dagger}$ & $\begin{array}{c}4.3(-7.6- \\
16.2) \\
\end{array}$ & $0.015^{\ddagger}$ \\
\hline Right cervical tilt $\left(^{\circ}\right)$ & $\begin{array}{c}33.8 \\
(11.8) \\
\end{array}$ & $\begin{array}{c}38.1 \\
(12.2) \\
\end{array}$ & 0.053 & $36.8(10.0)$ & $\begin{array}{c}43.2 \\
(11.8) \\
\end{array}$ & $0.002^{\dagger}$ & $\begin{array}{c}3.7(-7.3- \\
14.8) \\
\end{array}$ & $0.020^{*}$ \\
\hline Left cervical tilt $\left(^{\circ}\right)$ & $\begin{array}{l}34.6 \\
(13.3)\end{array}$ & $\begin{array}{c}39.1 \\
(13.1)\end{array}$ & 0.113 & $35.4(12.2)$ & $\begin{array}{c}43.1 \\
(11.7)\end{array}$ & $0.001^{\dagger}$ & $\begin{array}{c}2.0(-10.0- \\
14.0)\end{array}$ & 0.002 \\
\hline Right cervical rotation $\left({ }^{\circ}\right)$ & $\begin{array}{c}44.6 \\
(13.3) \\
\end{array}$ & $\begin{array}{c}47.5 \\
(15.2) \\
\end{array}$ & 0.084 & $48.2(17.8)$ & $\begin{array}{c}55.7 \\
(10.9) \\
\end{array}$ & $0.001^{\dagger}$ & $\begin{array}{c}8.2(-6.4- \\
22.9) \\
\end{array}$ & $0.001^{*}$ \\
\hline Left cervical rotation $\left({ }^{\circ}\right)$ & $\begin{array}{l}47.1 \\
(16.0) \\
\end{array}$ & $\begin{array}{c}47.8 \\
(15.1) \\
\end{array}$ & 0.783 & $50.5(15.3)$ & $\begin{array}{c}58.8 \\
(13.2) \\
\end{array}$ & $0.001^{\dagger}$ & $\begin{array}{c}10.3(-4.2- \\
24.8) \\
\end{array}$ & $0.001^{\ddagger}$ \\
\hline
\end{tabular}

$\mathrm{mm}$ - millimeter; ${ }^{\circ}$ - degree; SD - standard deviation $( \pm)$; CI - confidence interval. ${ }^{\dagger}$ There was statistical difference by t-test for paired samples; ${ }^{\ddagger}$ There was statistical difference by the ANOVA with Bonferroni post hoc test. Source: Authors.

\section{Discussão}

Several instruments were used to evaluate the degree of severity of TMD, such as the Fonseca Anamnestic Index (Chaves et al., 2008; Fonseca et al., 1994), consisting of a simple questionnaire, which is preferred in epidemiological research for classifying the degree of severity of TMD (Campos et al., 2009), and used in conjunction with the Helkimo Index, which classifies individuals according to the degree of severity of their dysfunction (Parente \& Cerdeira, 2013). 
A high rate of dysfunction was observed in this study's young population (32 volunteers, who were all college students). The study by Pinto et al (2017), showed a higher incidence of TMD signs and symptoms in young adults, aged 19 to 24 years, who comprised $70.2 \%$ from a total of 199 participants. This fact demonstrates the susceptibility of young people to the onset of symptoms. Another interesting point is the relationship between age, signs, and symptoms. Further, the fact that all were college students, points to a population being subject to various factors, whether physical, psychological, or emotional. According to gender distribution, there was a predominance of females (87.5\%) over males $(12.5 \%)$. These findings can be confirmed by previously published studies, such as Pinto et al (2017), in which, from a sample of 318 participants, $69.3 \%$ were females with some degree of TMD, reinforcing the idea that the presence of this dysfunction is higher in females, and may be related to physiological differences between genders, such as hormonal variations, muscle structure, tissue sagging, and lower pain thresholds found in females (Bezerra et al., 2012; Ferreira et al., 2015; A. L. Pinto et al., 2015).

In general, the clinical findings of people with TMD can be summarized as clicks; crepitations and joint contractures; muscle tension with decreased ROM angles for opening; lateralization; protraction; and retraction, which are predominantly associated by the presence of pain, which makes it the main factor for the impairment and depredation of TMJ functionality, such as the fatigue process of the facial and cervical muscles. However, the main deleterious effect of pain is decreased mandibular mobility (Andrade \& Frare, 2008; Arenhart et al., 2013; Dantas et al., 2015). According to the data found in this study, the present variables showed homogeneity between the CG and IG regarding the presence of pain on palpation during the pre-intervention evaluation process. Concerning the angulation and classification of mandible mobility levels, measured by pachymetry, Dworkin et al (1990), state that in adults the mean for the maximum limit of mandibular opening is between 53 $\mathrm{mm}$ and $58 \mathrm{~mm}$. However, Lelles et al (2010), observed that most patients' values of maximal mouth opening was less than 33 $\mathrm{mm}$, but in one of their patients a value of $51 \mathrm{~mm}$, ranging from $40 \mathrm{~mm}$ to $60 \mathrm{~mm}$ was found. A shortage of literary findings can be observed relating to the measurements of the normality standards since this fact is dependent on each individual's anatomical and physiological factors. Regarding cervical angulation, there is a decrease when compared to normal values present in the literature, which may be correlated to the fact that cranial and cervical spine movements occur in association with the activation of the masticatory muscles and mandibular movements. In other words, the whole postural mechanism that acts on the head also participates in the control of the mandibular posture (Biasotto-Gonzalez, 2005).

Knowing that the laser penetration power is relatively high, the results are satisfactory regarding musculoskeletal therapy, considering its anti-inflammatory, analgesic, healing, and modulating effects on cell activity (Andrade \& Frare, 2008; Kato et al., 2006; Magri et al., 2017). Starting from the analysis of the results found in the present study, the decrease in muscle pain is relevant, especially in the IG, who used the LLLT. In this, there was an increase in individuals who rated their pain as "0" (no pain), after application. Fikackova et al (2007), claim that the benefits provided by laser in the treatment of TMJ disorders have been successful in response to the analgesic effects generated by increased beta-endorphin levels, pain thresholds, as well as regulation of the mediators of pain and inflammation, such as bradykinin reduction and histamine release, intensification of lymph flow, reduced edema and pain, increased blood supply, decreased inflammatory period, besides allowing greater muscle relaxation.

Considering that laser therapy has beneficial repercussions on pain, Shinozaki et al. (2006), found that after laser application on painful points of the temporal and masseter muscles, and directly in the joint region, there was relief from painful symptoms as well as muscle relaxation by breaking the pain-spasm-pain cycle, resulting in the recovery of mandibular movements, reaching their expected angles, leading to the belief in the beneficial effects of laser in relation to improved joint ROM. These statements contribute to the data presented in this study, which showed a significant improvement regarding the increase in the measures of joint mobility of the mandible and cervical spine. Therefore, there were statistical differences between the CG and IG, and the IG obtained significant increases concerning the measures. Gama et al. (2015), concluded that 
the use of LLLT was very effective in improving the ROM of mouth opening, confirmed by biophotogrammetry and pain reduction by the VAS.

\section{Study Limitations}

Although this study was conducted with a considerably large number of participants, there were difficulties in their recruitment and permanence during the research, with many dropouts and even objections to participation, especially during examination periods.

\section{Conclusion}

This study is unprecedented because it is the first in the region to investigate the effect of laser therapy on TMD. Thus, it is concluded that LLLT promotes a significant reduction in pain on palpation, improvement of oral and cervical spine ROM. According to the findings, this therapy generates immediate and lasting benefits, allowing it to be widely used as a therapeutic approach in the treatment of TMD. Thus, more research is needed relating the therapeutic laser and LED in the treatment of temporomandibular disorders, as well as the use of kinesiological ultrasound and thermography to assess their effects on this joint.

\section{References}

Aires, C. C. G., Peixoto, L. dos S. F., Lima, I. F. M. de, Silva, C. P. da, \& Vasconcellos, R. J. D. H. (2020). Atualizações e avanços na etiopatogenia e tratamento dos tumores da articulação temporomandibular. Research, Society and Development, 9(10), e7139109104. https://doi.org/10.33448/rsd-v9i10.9104

Andrade, T., \& Frare, J. (2008). Estudo comparativo entre os efeitos de técnicas de terapia manual isoladas e associadas à laserterapia de baixa potência sobre a dor em pacientes com disfunção temporomandibular. Revista Gaucha de Odontologia, 56(3), 287-295.

Arenhart, R., Lazarotto, R., \& Thomé, K. (2013). Tratamento fisioterapêutico na disfunção temporomandibular: um estudo de caso. Revista FisiSenectus, 1, 109. https://doi.org/10.22298/rfs.2013.v1.n0.1759

Bag, A. K., Gaddikeri, S., Singhal, A., Hardin, S., Tran, B., Medina, J., \& Cura, J. (2014). Imaging of the temporomandibular joint: An update. World Journal of Radiology, 6(8), 567. https://doi.org/10.4329/wjr.v6.i8.567

Bezerra, B. P. N., Ribeiro, A. I. A. M., Farias, A. B. L. de, Farias, A. B. L. de, Fontes, L. de B. C., Nascimento, S. R. do, Nascimento, A. S., \& Adriano, M. S. P. F. (2012). Prevalência da disfunção temporomandibular e de diferentes níveis de ansiedade em estudantes universitários. Revista Dor, 13(3), 235-242. https://doi.org/10.1590/S1806-00132012000300008

Biasotto-Gonzalez, D. A. (2005). Abordagem interdisciplinar das disfunções temporomandibulares.

Calixtre, L. B., Moreira, R. F. C., Franchini, G. H., Alburquerque-Sendín, F., \& Oliveira, A. B. (2015). Manual therapy for the management of pain and limited range of motion in subjects with signs and symptoms of temporomandibular disorder: a systematic review of randomised controlled trials. Journal of Oral Rehabilitation, 42(11), 847-861. https://doi.org/10.1111/joor.12321

Campos, J., Gonçalves, D., Camparis, C., \& Speciali, J. (2009). Confiabilidade de um formulário para diagnóstico da severidade da disfunção temporomandibular. Rev Bras Fisioter, São Carlos, 13(1), 38-43.

Chaudhry, H., Mundi, R., Singh, I., Einhorn, T., \& Bhandari, M. (2008). How good is the orthopaedic literature. Indian J Orthop, 42(2), 144-149.

Chaves, T. C., Oliveira, A. S. de, \& Grossi, D. B. (2008). Principais instrumentos para avaliação da disfunção temporomandibular, parte I: índices e questionários; uma contribuição para a prática clínica e de pesquisa. Fisioterapia e Pesquisa, 15(1), 92-100. https://doi.org/10.1590/S180929502008000100015

Damasceno, F. M., \& Barbieri, L. G. (2014). O tratamento fisioterapêutico nas disfunções da articulação temporomandibular: uma revisão integrativa. EFDeportes.Com, 18(188).

Dantas, A. M. X., Santos, E. J. L. dos, Vilela, R. M., \& Lucena, L. B. S. de. (2015). Perfil epidemiológico de pacientes atendidos em um Serviço de Controle da Dor Orofacial. Revista de Odontologia Da UNESP, 44(6), 313-319. https://doi.org/10.1590/1807-2577.1065

Dworkin, S. F., Huggins, K. H., LeResche, L., Von Korff, M., Howard, J., Truelove, E., \& Sommers, E. (1990). Epidemiology of Signs and Symptoms in Temporomandibular Disorders: Clinical Signs in Cases and Controls. The Journal of the American Dental Association, 120(3), 273-281. https://doi.org/10.14219/jada.archive.1990.0043

Ferreira, J. B., Morais, K. C. S. de, Cirqueira, R. P., \& Matos, C. S. (2015). Tratamento fisioterapêutico nas disfunções temporomandibulares. InterScientia, $3(1), 123-146$. 
Fikácková, H., Dostálová, T., Navrátil, L., \& Klaschka, J. (2007). Effectiveness of Low-Level Laser Therapy in Temporomandibular Joint Disorders: A Placebo-Controlled Study. Photomedicine and Laser Surgery, 25(4), 297-303. https://doi.org/10.1089/pho.2007.2053

Fonseca, D. M. da, Bonfante, G., Valle, A. L. do, \& Freitas, S. F. T. de. (1994). Diagnóstico pela anamnese da disfunção craniomandibular / Diagnosis of the craniomandibular disfunction through anamnesis. Revista Gaucha de Odontologia, 42(1), 23-28.

Freitas, W. M. T. de M., Santos, A. K. F. dos, Saliba, E. D. M., \& Silva, E. A. Da. (2015). Avaliação da qualidade de vida e da dor em indivíduos com disfunção temporomandibular. Revista Pesquisa Em Fisioterapia, 5(3), 210-217. https://doi.org/10.17267/2238-2704rpf.v5i3.636

Gama, B. F. da, Barros, F. A. M., Cardoso, M. B. S. C., \& Soares, M. A. (2015). Efeito da laserterapiade baixa potência em pacientes com disfunção cranio cérvico-mandibular miogênica- análise através da biofotogrametria -estudo duplo cego. Biológicas \& Saúde, 5(17).

Garcia, J. D., \& Oliveira, A. A. de C. (2011). A Fisioterapia nos sinais e sintomas da disfunção da articulação temporomandibular (ATM). Revista Hórus, 6(1), $111-122$.

Kato, M. T., Kogawa, E. M., Santos, C. N., \& Conti, P. C. R. (2006). TENS and low-level laser therapy in the management of temporomandibular disorders. Journal of Applied Oral Science, 14(2), 130-135. https://doi.org/10.1590/S1678-77572006000200012

Leles, C. R., Neto, J. J. S. M., Giro, E. M. A., \& Compagnoni, M. A. (2010). Valores normais da amplitude do movimento mandibular em crianças. Brazilian Dental Science, 3(2). https://doi.org/10.14295/bds.2000.v3i2.98

Lima, L. F. C., Silva, F. A. de J. C., Monteiro, M. H. A., \& Oliveira Júnior, G. (2020). Depressão e ansiedade e a associação com as disfunções temporomandibulares- revisão de literatura. Research, Society and Development, 9(7), e579974540. https://doi.org/10.33448/rsd-v9i7.4540

Magri, L. V., Carvalho, V. A., Rodrigues, F. C. C., Bataglion, C., \& Leite-Panissi, C. R. A. (2017). Effectiveness of low-level laser therapy on pain intensity, pressure pain threshold, and SF-MPQ indexes of women with myofascial pain. Lasers in Medical Science, 32(2), 419-428. https://doi.org/10.1007/s10103$016-2138-x$

Malavolta, E. A., Demange, M. K., Gobbi, R. G., Imamura, M., \& Fregni, F. (2011). Ensaios clínicos controlados e randomizados na ortopedia: dificuldades e limitações. Revista Brasileira de Ortopedia, 46(4), 452-459. https://doi.org/10.1590/S0102-36162011000400018

Maria, S., \& Andrade, O. D. E. (2013). RESOLUÇÃO $N^{\circ}$ Diretrizes e O Plenário do Normas Conselho Nacional Regulamenta de Saúde em sua doras de 240 a Reunião Pesquisas Ordinária, realizada Envolvendo Seres dezembro de 2012 , I S de suas no uso competências regimentais e conferidas pela Lei.

Parente, I. A., \& Cerdeira, D. de Q. (2013). Disfunção temporomandibular: a avaliação fisioterapêutica em discentes de uma instituição de ensino superior do município de Sobral-Ceará. SANARE: Revista de Políticas Públicas, 12(2).

Pinto, A. L., Gomes Júnior, V. F. F., Mesquita, C. M. de, Ripardo, E. C. do N., Silva, E. F. da, Penalber, G. M. L., \& Costa, J. M. da. (2015). Prevalência da disfunção temporomandibular e qualidade de vida em acadêmicos de Fisioterapia. J. Health Sci. Inst, 33(4), 371-375.

Pinto, R. G. S., Leite, W. M. A., Sampaio, L. da S., \& Sanchez, M. de O. (2017). Association between temporomandibular signs and symptoms and depress ion in undergraduate students: descriptive study. Revista Dor, 18(3), 217-224. https://doi.org/10.5935/1806-0013.20170105

Prado, J. M. do, Kurebayashi, L. F. S., \& Silva, M. J. P. da. (2018). Auriculoterapia verdadeira e placebo para enfermeiros estressados: ensaio clínico randomizado. Revista Da Escola de Enfermagem Da USP, 52. https://doi.org/10.1590/s1980-220x2017030403334

Shinozaki, E. B., Paiva, G., Zanin, F. A. A., \& Junior, A. B. (2006). Avaliação eletromiográoica de pacientes com DTM após a laserterapia. Revista Gaucha de Odontologia, 54(4), 334-339.

Silva, A., \& Santos, G. (2014). Atuação da fisioterapia no tratamento da disfunção temporomandibular. Fisioterapia Brasil, 15(2).

Silva, G. C. B. da, Viana, E. de P., Medeiros, F. de L., Alves, L. N. S., Vasconcelos, M. G., \& Vasconcelos, R. G. (2021). Distúrbios intracapsulares da articulação temporomandibular: da semiologia à terapêutica: uma revisão de literatura. Research, Society and Development, 10(3), e12510313189. https://doi.org/10.33448/rsd-v10i3.13189

Sobral, A. P. T., Sobral, S. de S., Giacon, G. G., Campos, T. M., Horliana, A. C. R. T., Fernandes, K. P. S., Bus sadori, S. K., \& Motta, L. J. (2020). Phototherapy versus Occlusal Splint to control painful symptoms in Temporomandibular Disorder: controlled, randomized cost-effectiveness clinical trial Research, Society and Development, 9(11), e66991110251. https://doi.org/10.33448/rsd-v9i11.10251

Soucacos, P., Johnson, E., \& Babis, G. (2008). Randomised controlled trials in orthopaedic surgery and traumatology: overview of parameters and pitfalls. Injury, 39(6), 636-642.

Vilar, E. G. S., Pereira, E. de S. B. M., Eleutério, R. G., Trazzi, B. F. M., \& Silva, W. S. da. (2020). Indicações cirúrgicas de deslocamento do disco articular da articulação temporomandibular / Surgical indications for the treatment of displacement of the articular disk of the temporary mandibular joint. Brazilian Journal of Health Review, 3(5), 13790-13809. https://doi.org/10.34119/bjhrv3n5-195 